\title{
Estimating chemical composition of atmospheric deposition fluxes from mineral insoluble particles deposition collected in the western Mediterranean region
}

\author{
Yinghe Fu ${ }^{1}$, Karine Desboeufs ${ }^{1}$, Julie Vincent ${ }^{1}$, Elisabeth Bon Nguyen ${ }^{1}$, Benoit Laurent $^{1}$, Remi Losno ${ }^{1, a}$, and \\ François Dulac ${ }^{2}$ \\ ${ }^{1}$ Laboratoire Interuniversitaire des Systèmes Atmosphériques (LISA), UMR7583 CNRS, Université Paris 7 Denis Diderot, \\ Université Paris-Est Créteil, Institut Pierre-Simon Laplace, Créteil, 94010, France \\ ${ }^{2}$ Laboratoire des Sciences du Climat et de l'Environnement (LSCE), UMR 8212 CEA-CNRS-UVSQ, \\ Institut Pierre-Simon Laplace, Gif-sur-Yvette, 91190, France \\ anow at: Institut de Physique du Globe de Paris, Paris, France \\ Correspondence to: Yinghe Fu (yinghe.fu@lisa.u-pec.fr)
}

Received: 5 April 2017 - Discussion started: 24 May 2017

Revised: 26 September 2017 - Accepted: 27 September 2017 - Published: 15 November 2017

\begin{abstract}
In order to measure the mass flux of atmospheric insoluble deposition and to constrain regional models of dust simulation, a network of automatic deposition collectors (CARAGA) has been installed throughout the western Mediterranean Basin. Weekly samples of the insoluble fraction of total atmospheric deposition were collected concurrently on filters at five sites including four on western Mediterranean islands (Frioul and Corsica, France; Mallorca, Spain; and Lampedusa, Italy) and one in the southern French Alps (Le Casset), and a weighing and ignition protocol was applied in order to quantify their mineral fraction. Atmospheric deposition is both a strong source of nutrients and metals for marine ecosystems in this area. However, there are few data on trace-metal deposition in the literature, since their deposition measurement is difficult to perform. In order to obtain more information from CARAGA atmospheric deposition samples, this study aimed to test their relevance in estimating elemental fluxes in addition to total mass fluxes. The elemental chemical analysis of ashed CARAGA filter samples was based on an acid digestion and an elemental analysis by inductively coupled plasma atomic emission spectroscopy (ICP-AES) and mass spectrometry (MS) in a clean room. The sampling and analytical protocols were tested to determine the elemental composition for mineral dust tracers ( $\mathrm{Al}, \mathrm{Ca}, \mathrm{K}, \mathrm{Mg}$ and $\mathrm{Ti})$, nutrients $(\mathrm{P}$ and $\mathrm{Fe}$ ) and trace metals $(\mathrm{Cd}, \mathrm{Co}, \mathrm{Cr}, \mathrm{Cu}, \mathrm{Mn}, \mathrm{Ni}, \mathrm{V}$ and $\mathrm{Zn}$ ) from simulated wet deposition of dust analogues and traffic soot. The
\end{abstract}

relative mass loss by dissolution in wet deposition was lower than $1 \%$ for $\mathrm{Al}$ and $\mathrm{Fe}$, and reached $13 \%$ for $\mathrm{P}$ due to its larger solubility in water. For trace metals, this loss represented less than $3 \%$ of the total mass concentration, except for $\mathrm{Zn}, \mathrm{Cu}$ and $\mathrm{Mn}$ for which it could reach $10 \%$, especially in traffic soot. The chemical contamination during analysis was negligible for all the elements except for $\mathrm{Cd}$, which has a very low concentration in dust. Tests allowed us to conclude that the CARAGA samples could be used to estimate the contents of nutrients and trace metals in the limits of loss by dissolution. Chemical characterization of CARAGA deposition samples corresponding to the most intense dust deposition events recorded between 2011 and 2013 has been performed and showed elemental mass ratios consistent with the ones found in the literature for Saharan dust. However, the chemical analysis of CARAGA samples revealed the presence of some anthropogenic signatures, for instance high $\mathrm{Zn}$ concentrations in some samples in Lampedusa, and also pointed out that mineral dust can be mixed with anthropogenic compounds in the deposition samples collected on Frioul. Results showed that the chemical analysis of CARAGA ashed samples can be used to trace the origins of elemental deposition. The elemental atmospheric fluxes estimated from these chemical analyses of samples from the CARAGA network of weekly deposition monitoring constitute the first assessment of mass deposition fluxes of trace metals and $\mathrm{P}$ during intense dust deposition events at the scale of the western Mediter- 
ranean Basin. The mass fluxes strongly depend on the distance from dust sources and the most intense events, while proximity from anthropogenic sources strongly impacted the masse fluxes of $\mathrm{Zn}$ and $\mathrm{Cu}$ at Lampedusa and Frioul.

\section{Introduction}

The Mediterranean Basin is a receptor for the deposition of particles emitted in surrounding coastal urban areas and continents. These deposited particles can have both natural (e.g. Saharan dust and biogenic emissions) and anthropogenic origins (e.g. Loÿe-Pilot and Martin, 1996; Kanakidou et al., 2011). Atmospheric inputs supply as much nutrients as riverine inputs in the Mediterranean and are less confined to coastal waters (e.g. Moon et al., 2016; Richon et al., 2017). They play a significant role in marine nutrient cycles during the Mediterranean water stratification period, i.e. from May to September. This is the case for $\mathrm{P}$ and N macronutrients (Loÿe-Pilot et al., 1990; Pulido-Villena et al., 2010) and Fe micronutrients (Bonnet and Guieu, 2006). Saharan dust deposition is also considered an input of trace metals, such as $\mathrm{Co}, \mathrm{Ni}, \mathrm{Mo}, \mathrm{Mn}, \mathrm{Zn}$ and $\mathrm{Cd}$, for the Mediterranean Sea, which play an essential role in phytoplanktonic activity (Morel and Hudson, 1985). For instance, $\mathrm{N}_{2}$ fixation and growth of diazotrophs could be controlled by dust inputs of trace metals (Ridame et al., 2011).

The ADIOS programme, based on a network of deposition measurements with a common protocol deployed over the same period at nine stations throughout the basin, provides key information for studying the spatial variability of nutrients and trace metals deposited in the Mediterranean area, but it was limited to only 1 year (June 2001-May 2002) with a monthly resolution that cannot isolate high-deposition events (Guieu et al., 2010). The measured elemental fluxes show a high spatial variability and suggest that the dustderived $\mathrm{Fe}$ deposition is higher in the north-western basin. For P deposition, the measurements seem to indicate a longitudinal gradient with significantly lower values in the eastern Mediterranean Basin, attributed equally to dust and anthropogenic inputs. However, due to the high temporal variability of desert dust events transported over the Mediterranean Basin, it is difficult to conclude much from a 1-year data set of the chemical elements associated with dust. To do that, a long-term and large-scale deposition sampling network is required (Schulz et al., 2012). In order to obtain a long timeseries of deposition mass fluxes at several sampling sites, a CARAGA (Collecteur Automatique de Retombées Atmosphériques insolubles à Grande Autonomie) collector has been developed (Laurent et al., 2015) and implemented at five sites in the western Mediterranean region (Vincent et al., 2016). This collector has up to 6 months autonomy without human intervention. To do that, only the insoluble fraction of total deposition is sampled on filters, excluding the soluble fraction of the deposition, which can be difficult to preserve over months.

Samples of atmospheric deposition have automatically been collected by CARAGA since 2011 at five sites: Le Casset (SE France), Corsica (France), Frioul (France), Mallorca (Spain) and Lampedusa (Italy). Measured total mass fluxes of atmospheric deposition and the weighing and ignition protocols used to quantify the mineral deposition are presented in Laurent et al. (2015) and Vincent et al. (2016). In the present study, we investigate the possibility of using the CARAGA ashed samples to estimate the elemental mass deposition flux of nutrients and trace metals. Firstly, we tested the elemental composition changes during the sampling and treatment protocol of deposition samples with aerosol analogues. Secondly, we estimated the nutrients and trace-metal fluxes of the most intense dust deposition events associated with dust events over the western Mediterranean Basin between 2011 and 2013.

\section{Materials and methods}

\subsection{Sampling of insoluble deposition and total mass measurements}

Weekly deposition samples were collected between 2011 and 2013 with CARAGA collectors at five stations in the western Mediterranean Basin presented in Fig. 1. The site positions were selected to cover the western basin by integrating eastwest and north-south gradients:

1. Le Casset $\left(44^{\circ} 59^{\prime} \mathrm{N}, 6^{\circ} 28^{\prime} \mathrm{E}, \mathrm{S}\right.$-E France at $1850 \mathrm{~m}$ in altitude, rural area, $\sim 170 \mathrm{~km}$ from sea shore) - a previous study on the composition of rainwater (Coddeville et al., 2002) showed that this site was highly influenced by the anthropogenic emissions and the crustal sources around the Mediterranean Basin and northern Africa. Other European areas (e.g. Italy) can influence the concentrations recorded at Le Casset.

2. Corsica $\left(43^{\circ} 00^{\prime} \mathrm{N}, 9^{\circ} 21^{\prime} \mathrm{E}\right.$, France, at $75 \mathrm{~m}$ in altitude, $300 \mathrm{~m}$ from sea shore) - the chemical composition of aerosol on this site was studied during the ChArMEx campaign (June-August 2013) and the results showed the influence of elemental carbon-containing particles, issued in part from fossil fuel, biomass burning and ship traffic, sea-salt particles and secondary organic aerosol (Mallet et al., 2016; Arndt et al., 2017).

3. Frioul $\left(43^{\circ} 16^{\prime} 30^{\prime \prime} \mathrm{N}, 5^{\circ} 18^{\prime} 28^{\prime \prime} \mathrm{E}\right.$, France, at $45 \mathrm{~m}$ in altitude, in front of Marseille (city of 1.57 million population according to INSEE 2012) - previous dry deposition measurements operated in the Frioul islands have shown, from lipid analyses, a significant contribution of terrestrial particles, plant debris and meat cooking residues in the deposited particles (Rontani et al., 2012). 


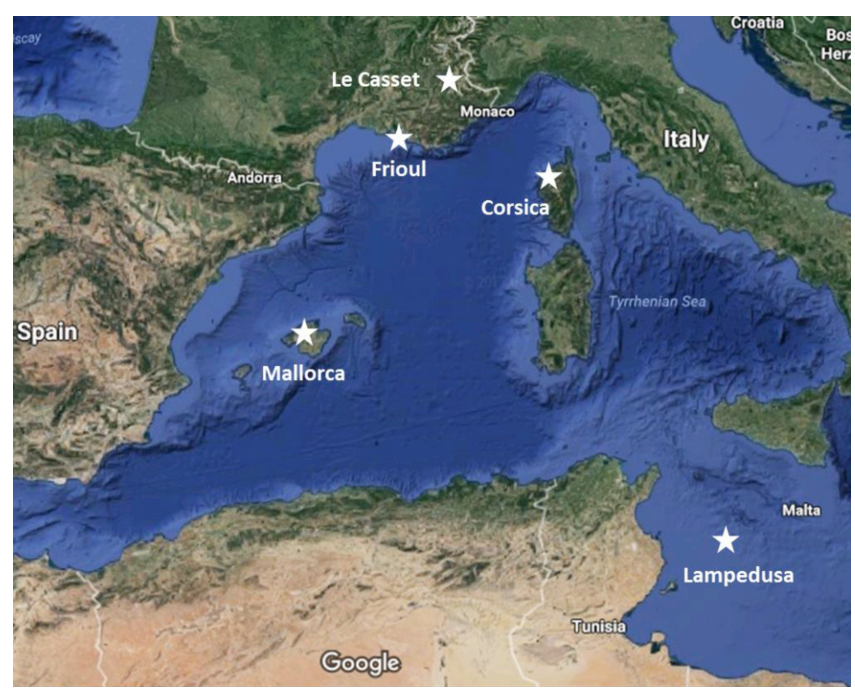

Figure 1. Location of the CARAGA sampling sites in the western Mediterranean Basin: Le Casset, Corsica, Frioul, Mallorca and Lampedusa.

4. Mallorca $\left(39^{\circ} 16^{\prime} \mathrm{N}, 3^{\circ} 03^{\prime} \mathrm{E}\right.$, Spain, at $7 \mathrm{~m}$ in altitude, $70 \mathrm{~m}$ from the seashore) - this site has never been used for atmospheric studies, so no information on the source influence is available.

5. Lampedusa $\left(35^{\circ} 31^{\prime} \mathrm{N}, 12^{\circ} 37^{\prime} \mathrm{E}\right.$, Italy, at $45 \mathrm{~m}$ in altitude, $\sim 20 \mathrm{~m}$ from the north-western coast). The site on Lampedusa is a station for climate observations, maintained by ENEA (the Italian Agency for New Technologies, Energy and Sustainable Economic Development). Various atmospheric parameters are monitored at this station: greenhouse gas concentrations, aerosol chemical and optical properties, total ozone and radiative budget (e.g. Artuso et al., 2009; Becagli et al., 2012; Gómez-Amo et al., 2013). The results show that the $\mathrm{PM}_{10}$ concentrations are influenced by marine and ship emissions to which Saharan dust events in spring are added (Becagli et al., 2012; Mallet et al., 2016). Regarding trace-metal concentrations, $\mathrm{Ni}$ and $\mathrm{V}$ in the submicronic fraction are mainly due to heavy oil combustion associated with ship traffic (Becagli et al., 2012, 2017).

In the CARAGA collectors, dry and wet deposition are collected by a funnel $\left(0.2 \mathrm{~m}^{2}\right)$ over 1 week starting on Thursday at noon. At the end of the week, the funnel is rinsed with $250 \mathrm{~mL}$ of ultrapure water. Rinse water and rainwater pass through an AA Millipore ${ }^{\circledR}$ cellulose ester filter with a $0.8 \mu \mathrm{m}$ porosity in order to collect the insoluble fraction of the deposition. A complete description of the CARAGA collector and sampling network can be found in Laurent et al. (2015) and Vincent et al. (2016). After being brought back to the laboratory, collected filters were ashed following a progressive increase in temperature up to $550^{\circ} \mathrm{C}$ in order to destroy and vaporize the filter and organic matters. The mineral deposi- tion mass, excluding volatile and organic matter, was estimated by weighing the ashed samples (Laurent et al., 2015), and the ashes were stored in acid-cleaned Eppendorf tubes.

From 2011 to 2013, 108 samples corresponding to the most intense weekly dust deposition samples were studied by Vincent et al. (2016), and a Saharan origin was identified for 107 selected samples by using satellite data and air mass trajectories. The selected samples account for 84,78 and $73 \%$ in mass of the total deposition in Lampedusa (37 samples), Mallorca (21 samples) and Corsica (11 samples), and it contributes for around $50 \%$ in Frioul (21 samples) and Le Casset (17 samples). A complete description of the treatment and selection of samples can be found in Vincent et al. (2016).

\subsection{Analytical protocol}

In order to further obtain their elemental composition, ashed CARAGA samples were digested using a digestion protocol adapted from Heimburger et al. (2013). About $20 \mathrm{mg}$ of ashed samples were weighed and transferred to a Savillex ${ }^{\text {TM }}$ PFA digestion vessels with $0.5 \mathrm{~mL}$ of ultrapure water to avoid the loss of samples. The samples were then digested using $2.5 \mathrm{~mL}$ of mixture of Suprapur ${ }^{\circledR}$ acid $(1 \mathrm{~mL} \mathrm{HCl} 30 \%, 1 \mathrm{~mL}$ $\mathrm{HNO}_{3} 65 \%$ and $0.5 \mathrm{~mL} \mathrm{HF} 40 \%$ ) during $14 \mathrm{~h}$ in an air oven at $130{ }^{\circ} \mathrm{C}$ in closed vessels. When the digestion vessels were cooled, the acid was completely evaporated on a heater plate. Overall, $130 \mu \mathrm{L}$ of suprapur ${ }^{\circledR} \mathrm{HNO}_{3}$ and then $13 \mathrm{~mL}$ of ultrapure water was added. Finally, the contents of each vessel were transferred into an acid-cleaned $15 \mathrm{~mL}$ tube for elemental analysis. The full analysis was carried out in a ISO class 5 clean room with material washed with Ultrapur then Suprapur ${ }^{\circledR} \mathrm{HCl}$. At least three blanks (ashed filters without particles) were produced for each set of acid digestion in order to estimate the potential contamination during the protocol.

Analyses were performed with a SPECTRO ARCOS (http://www.spectro.com) inductively coupled plasmaatomic emission spectrometer (ICP-AES) for markers of desert dust ( $\mathrm{Al}, \mathrm{Ca}, \mathrm{K}, \mathrm{Mg}$, $\mathrm{Na}$ and $\mathrm{Ti})$, nutrients $(\mathrm{P}$ and $\mathrm{Fe}$ ) and trace metals $(\mathrm{Cd}, \mathrm{Co}, \mathrm{Cr}, \mathrm{Cu}, \mathrm{Mn}, \mathrm{Ni}, \mathrm{V}$ and $\mathrm{Zn})$. Due to digestion with hydrofluoric acid and the high volatility of formed $\mathrm{SiF}_{4}$, we could not obtain the contents of silicon.

\subsection{Test of elemental mass loss during the CARAGA protocol}

In order to estimate the change in elemental composition during the CARAGA sampling and treatment protocol, tests have been carried on analogues of typical Saharan dust or soot particles, which were subject to the collection protocol and then ignition in the laboratory.

Wet deposition being the major pathway to solubilize nutrients and trace metals, analogues of typical wet deposition CARAGA samples were made by simulating rainwater containing two kinds of particles: dust and soot, which are the 
main insoluble aerosols (Ault et al., 2011). Desert dust samples were prepared from the fine fraction of soils $(<20 \mu \mathrm{m})$ collected in semi-arid areas of Douz (Tunisia) and Banizoumbou (Niger). The elemental solubility in desert dust varies depending on several factors, the mineralogical composition of the particles being one of the major ones (Journet et al., 2008). We selected these soils because their mineralogical and elemental compositions were well known (Guieu et al., 2010; Paris et al., 2011; Desboeufs et al., 2014a). In addition, they represent two extreme mineralogical and chemical characteristics observed in the dust emission zones of northern Africa, influencing the western Mediterranean atmosphere (Bergametti et al., 1989): the Douz soil is rich in calcium carbonate and clay $(\mathrm{Ca} / \mathrm{Al}=4.16$ and $\mathrm{Fe} / \mathrm{Al}=0.51)$ and the Banizoumbou soil is rich in iron oxides and quartz $(\mathrm{Ca} / \mathrm{Al}=0.06$ and $\mathrm{Fe} / \mathrm{Al}=0.63$ ) (Formenti et al., 2014). Soot samples are traffic particles collected in a tunnel in Paris. Indeed, black carbon measured in the western Mediterranean is mainly anthropogenic carbon-containing particles from combustion emission (Mallet et al., 2016).

Simulations of rainwater were made by adding $50 \pm 0.2 \mathrm{mg}$ of particles (fine fractions of soils or soot) into $250 \pm 2 \mathrm{~mL}$ of ultrapure water acidified at $\mathrm{pH}=4.7$ with Suprapur ${ }^{\circledR}$ sulfuric acid. This $\mathrm{pH}$ value and the sulfuric acid are characteristics of atmospheric conditions and are commonly used to mimic the release of trace metals from aerosol in rainwater (Desboeufs et al., 2001). After $30 \mathrm{~min}$ of contact time and automatic shaking, we reproduced the CARAGA sampling of wet deposition through filters and collected the filtrated solution. The time of $30 \mathrm{~min}$ corresponds to the most prevalent average time of rainfall in the western Mediterranean Basin (Rysman et al., 2013). A day $(24 \mathrm{~h})$ later, we rinsed the filter holder using $100 \pm 5 \mathrm{~mL}$ of ultrapure water to simulate the rinsing step of the CARAGA protocol. We produced three replicates for each type of particle. The filtrated rinsing water was collected. Dissolved nutrients and trace-metal concentrations were determined in the filtrated simulated rainwater and rinsing water to estimate the loss associated with the soluble fraction during the collection of the insoluble fraction. The dissolved concentrations were analysed with a ICP-AES for major elements: $\mathrm{Al}, \mathrm{Ca}, \mathrm{P}, \mathrm{Fe}$ and $\mathrm{Ti}$, and with a Thermo Fisher Scientific ${ }^{\mathrm{TM}}$ Element 2, high-resolution inductively coupled plasma mass spectrometer (HR-ICP-MS) for trace metals $\mathrm{Cd}, \mathrm{Co}, \mathrm{Cr}, \mathrm{Cu}, \mathrm{Mn}, \mathrm{Ni}, \mathrm{V}$ and $\mathrm{Zn}$. Blank values for rainwater corresponding to acidified ultrapure water without soils that passed through the collector $(n=3)$ were subtracted to the measured concentrations.

In order to assess the potential change of the sample elemental composition due to the calcination step, we simulated sampling of rainwater using the Douz and Banizoumbou soils with the above-described protocol but by adding $90 \mathrm{mg}$ of soils. After filtration and rinsing, filters were dried in the oven at $40^{\circ} \mathrm{C}$ for $2 \mathrm{~h}$ and then weighed, about $20 \mathrm{mg}$ of dry soil was collected in a clean Eppendorf tube, the rest (with filter) was ashed based on the CARAGA protocol, then weighed, and about $20 \mathrm{mg}$ was also collected in an Eppendorf tube. Both of them were digested for analysis by ICPAES and compared. This test was carried out in triplicates for each soil.

\subsection{Estimation of contamination during CARAGA protocol}

Using the proposed protocol 107 selected samples were digested and analysed for markers, nutrients and trace metals. In order to estimate the contamination and limit of detection (LoD) of the analytical protocol, nine blanks of CARAGA samples (filters exposed but not collected) were used and processed. Even if the protocol of chemical analysis was tested for $20 \mathrm{mg}$ of ashed samples, the mass of several CARAGA samples was inferior to $20 \mathrm{mg}$, especially the less intense deposition samples. In this case, the totality of ashed samples was used for acid digestion. The minimum sample mass was $2 \mathrm{mg}$. The weighing uncertainty was $\pm 0.2 \mathrm{mg}$. It was not significant ( $1 \%$ ) for samples of $20 \mathrm{mg}$, but for samples of $2 \mathrm{mg}$, it could represent $10 \%$ of uncertainty. However, these samples made a low contribution to total annual mass fluxes (Vincent et al., 2016). Therefore, we decided that the uncertainty in the weighing protocol was not significant for annual mass flux of nutrients and trace metals. We compared the lowest concentrations obtained for a $2 \mathrm{mg}$ sample with blanks to check the reliability of measured concentrations (Table 1 ).

For $\mathrm{P}, \mathrm{Cr}, \mathrm{Cu}$ and $\mathrm{Zn}$, concentrations of blank values were below the limit of detection, so we considered that contamination could be neglected. For elements except $\mathrm{Cd}$, blank concentrations were quantifiable and presented low variability but remained largely inferior to minimum concentrations in $2 \mathrm{mg}$ of CARAGA samples. Cd concentration was inferior to $\mathrm{LoD}$, so we could not estimate Cd content in samples with low mass. For calculations of mass fluxes, we subtracted these blanks values to elemental concentrations obtained in the CARAGA samples. We did not take into account $\mathrm{Cd}$ in the following study because of the large uncertainty on its concentrations.

\section{Results and discussion}

\subsection{Estimate of elemental mass loss during the CARAGA protocol}

Averages of elemental mass loss and the standard deviation of three replicates for three types of particles (soils of Douz and Banizoumbou, and traffic soot) during the sampling of wet deposition are presented in Table 2. Loss by dissolution during collection and rinsing has been calculated as fractional solubility:

$S=\frac{\text { Elemental mass in filtered and rinsed solution }}{\text { Elemental mass in initial particles }} \times 100 \%$. 
Table 1. Limit of detection (LoD; calculated with three times the standard deviation for nine blanks) and elemental concentrations in blanks and CARAGA samples (in ppb).

\begin{tabular}{llrrr}
\hline Elements & & LoD & $\begin{array}{r}\text { Mean for } \\
\text { blanks }\end{array}$ & $\begin{array}{r}\text { Sample } \\
(2 \mathrm{mg})\end{array}$ \\
\hline Marker & $\mathrm{Al}$ & 2.2 & $2.5 \pm 0.7$ & 1395.5 \\
elements & $\mathrm{Ti}$ & 0.16 & $0.11 \pm 0.05$ & 73.76 \\
\hline Nutrients & $\mathrm{Fe}$ & 0.4 & $0.9 \pm 0.1$ & 773.6 \\
& $\mathrm{P}$ & 6.2 & $<\mathrm{LoD}$ & 157.3 \\
\hline Trace & $\mathrm{Cd}$ & 0.29 & $0.63 \pm 0.07$ & $<\mathrm{LoD}$ \\
metals & $\mathrm{Co}$ & 0.57 & $0.64 \pm 0.19$ & 8.67 \\
& $\mathrm{Cr}$ & 0.6 & $<\mathrm{LoD}$ & 34.6 \\
& $\mathrm{Cu}$ & 1.0 & $<\mathrm{LoD}$ & 16.4 \\
& $\mathrm{Mn}$ & 0.4 & $0.8 \pm 0.1$ & 71.5 \\
& $\mathrm{Ni}$ & 0.9 & $1.2 \pm 0.3$ & 18.3 \\
& $\mathrm{~V}$ & 0.7 & $1.1 \pm 0.2$ & 22.1 \\
& $\mathrm{Zn}$ & 0.9 & $<\mathrm{LoD}$ & 36.0 \\
\hline
\end{tabular}

The largest mass losses were observed for major alkali and alkaline earth metals: $\mathrm{Ca}, \mathrm{K}, \mathrm{Mg}$ and $\mathrm{Na}$. $\mathrm{Al}$ and $\mathrm{Ti}$, which are the major tracers of dust, presented solubility lower than $1 \%$ for the two dust analogues. The low solubility of $\mathrm{Al}$ and $\mathrm{Ti}$ makes it possible to use them as markers of sources in CARAGA samples, but it is not the case for the ratios $\mathrm{K} / \mathrm{Al}$ and $\mathrm{Ca} / \mathrm{Al}$ typically used to characterize the desert dust sources (Scheuvens et al., 2013). For nutrients, the mass loss for $\mathrm{Fe}(0.11-0.68 \%)$ was lower than $1 \%$ for all types of aerosols analogues, whereas the maximum mass loss of $\mathrm{P}$ reached $13.3 \pm 2.3 \%$ in soils in Douz. The results on the fractional solubility were in agreement with the background on $\mathrm{P}$ and Fe solubility in mineral dust (Anderson et al., 2010) and in black carbon particles (Desboeufs et al., 2005). For trace metals, the mass loss was typically under $3 \%$ except for $\mathrm{Zn}(4.8-8.8 \%), \mathrm{Cu}(1.7-6.6 \%)$ and $\mathrm{Mn}(2.8-10.8 \%)$ for which the solubility was lower than $10 \%$. In the literature, few data are available on the aerosol fractional solubility in rainwater and in particular for dusty rain, solubility values of $\mathrm{Al}(0.24 \%), \mathrm{Fe}(0.06 \%), \mathrm{Cu}(8.37 \%)$ and $\mathrm{Mn}(5.62 \%)$ in rainwater in Istanbul reported by Başak and Alagha (2004) are consistent with this study. The solubility values are variable from one aerosol analogue to another: $\mathrm{Mn}$ present in the Banizoumbou soil is more soluble than in traffic soot, whereas $\mathrm{Cu}, \mathrm{Co}, \mathrm{Ni}, \mathrm{Cd}$ and $\mathrm{Zn}$ contained in traffic soot are more soluble than the ones in Banizoumbou soil. The ICPAES analysis performed on samples before and after the ignition protocol point out that elemental mass loss during the calcination was not significant for tracer elements ( $\mathrm{Al}$ and $\mathrm{Ti})$, nutrients ( $\mathrm{P}$ and $\mathrm{Fe}$ ) and trace metals $(\mathrm{Co}, \mathrm{Cr}, \mathrm{Cu}, \mathrm{Mn}$, $\mathrm{Ni}, \mathrm{V}$ and $\mathrm{Zn}$ ).

The tests emphasized that the main change in chemical composition between deposited aerosols and ashed CARAGA samples was due to the loss by dissolution during wet deposition and by rinsing. The composition of nutrient and trace metals obtained from simulated CARAGA samples were representative of initial dust and soot analogues with a maximum of $13 \%$ of underestimation for P, less than $10 \%$ for $\mathrm{Zn}, \mathrm{Cu}$ and $\mathrm{Mn}$ and less than $5 \%$ for other elements. Tests were carried out for wet deposition. In the case of dry deposition, particles are rinsed and the contact time with water is less than for wet deposition. Thus, the underestimation due to dissolution would probably be lower in the case of dry deposition. The highest uncertainty of $13 \%$ is inferior to the common discrepancy on the deposition fluxes estimated from different dry deposition samplers (Goosens and Rajot., 2008; López-García et al., 2013). To conclude, taking into account the underestimation of the soluble fraction, the CARAGA samples seem to be relevant for estimating the total deposition fluxes of $\mathrm{Al}, \mathrm{Fe}, \mathrm{P}, \mathrm{Co}, \mathrm{Cr}, \mathrm{Cu}, \mathrm{Ni}, \mathrm{Mn}, \mathrm{Ti}, \mathrm{V}$ and $\mathrm{Zn}$.

\subsection{Chemical characterization of CARAGA samples}

After sample analysis, weekly elemental mass fluxes for the 107 deposition samples were calculated from measured concentrations. These samples being associated with deposition of Saharan dust, we checked their chemical compositions with principal component analysis (PCA) and mass ratios $\mathrm{X} / \mathrm{Al}$, then compared them with Saharan dust composition in order to validate the use of the CARAGA samples to determine the origin of elemental deposition fluxes.

\subsubsection{Principal component analysis (PCA) for 107 CARAGA samples}

Principal component analysis was used to identify the possible sources of the deposition samples from the 107 intense events. Correlation between variables and factors for the elements $\mathrm{Al}, \mathrm{Fe}, \mathrm{P}, \mathrm{Ti}, \mathrm{Co}, \mathrm{Cr}, \mathrm{Cu}, \mathrm{Mn}, \mathrm{Ni}, \mathrm{V}$ and $\mathrm{Zn}$ and commutative variance for five sampling sites were presented in Table 3. For each site, 2-4 possible sources were identified, and the first source always contributed much more than half the variance of data, and the two first factors were extracted as principal components that explained $>82 \%$ of the variance of the sample data. The lower variances of the first factor explained 57.34 and $66.87 \%$ at sites Lampedusa and Frioul respectively, showing more influence from other sources at these two sampling sites. In the studied 107 samples, all elements were globally issued from a similar source for each site, but other sources (especially of $\mathrm{Zn}, \mathrm{Cu}, \mathrm{Cr}$, Co and $\mathrm{P}$ ) influenced the sampling sites too, especially at sites Lampedusa and Frioul. In order to identify the outlier samples, individual observations located on plane factors of 1,2 or 1, 3 are presented in Fig. 2, and the observations located higher (>1\%) on axis $Y$ (factor of 2 or 3 ) were considered outlier samples that were responsible for the low correlation between variables and the first factors for the studied elements. 
Table 2. Elemental mass loss in soils of Douz and Banizoumbou, and traffic soot during the collection and ignition of wet deposition. Standard deviation (SD) results from triplicate experiments. Al, Ca, P, K, Na and Mg have been measured by ICP-AES and other elements by HR-ICP-MS.

\begin{tabular}{|c|c|c|c|c|c|c|c|}
\hline \multirow[t]{2}{*}{ Elements } & & \multicolumn{2}{|c|}{ Soil of Douz } & \multicolumn{2}{|c|}{ Soil of Banizoumbou } & \multicolumn{2}{|c|}{ Traffic soot } \\
\hline & & Mean (\%) & $\mathrm{SD}(\%)$ & Mean (\%) & $\mathrm{SD}(\%)$ & Mean (\%) & $\mathrm{SD}(\%)$ \\
\hline \multirow[t]{6}{*}{ Markers } & $\mathrm{Ca}$ & 18.09 & 0.29 & 27.0 & 1.4 & 33.57 & 0.51 \\
\hline & $\mathrm{Al}$ & 1.09 & 0.13 & 0.39 & 0.05 & 0.61 & 0.03 \\
\hline & $\mathrm{Mg}$ & 3.43 & 0.03 & 30.40 & 0.51 & 8.81 & 0.18 \\
\hline & $\mathrm{Na}$ & 10.09 & 0.56 & 4.60 & 1.27 & 95.5 & 2.2 \\
\hline & K & 5.80 & 0.12 & 3.12 & 0.07 & 15.05 & 0.57 \\
\hline & $\mathrm{Ti}$ & 0.57 & 0.09 & 0.12 & 0.02 & 8.55 & 2.89 \\
\hline \multirow[t]{2}{*}{ Nutrients } & $\mathrm{P}$ & 13.3 & 2.3 & $*$ & $*$ & 10.3 & 1.0 \\
\hline & $\mathrm{Fe}$ & 0.68 & 0.13 & 0.19 & 0.03 & 0.11 & 0.005 \\
\hline \multirow{8}{*}{$\begin{array}{l}\text { Trace } \\
\text { metals }\end{array}$} & $\mathrm{Cd}$ & $*$ & $*$ & $*$ & $*$ & 4.97 & 0.78 \\
\hline & Co & 1.12 & 0.10 & 0.19 & 0.03 & 2.41 & 0.27 \\
\hline & $\mathrm{Cr}$ & 1.01 & 0.11 & 0.11 & 0.02 & 0.38 & 0.01 \\
\hline & $\mathrm{Cu}$ & 3.87 & 0.35 & 1.67 & 0.46 & 6.58 & 0.12 \\
\hline & $\mathrm{Mn}$ & 2.78 & 0.06 & 10.77 & 0.20 & 7.52 & 0.08 \\
\hline & $\mathrm{Ni}$ & 0.62 & 0.07 & $*$ & $*$ & 4.67 & 0.17 \\
\hline & $\mathrm{V}$ & 3.47 & 0.12 & 0.38 & 0.06 & 2.00 & 0.09 \\
\hline & $\mathrm{Zn}$ & 4.77 & 0.62 & 6.39 & 0.86 & 8.75 & 0.10 \\
\hline
\end{tabular}

* Elemental concentrations were under the limit of quantitation (LoQ), so we could not calculate the elemental loss.

Table 3. PCA factor loadings for 10 elements and for 107 samples. F is factor. Only loads larger than 0.3 (in absolute values) are reported. Loads larger than 0.6 are in bold.

\begin{tabular}{|c|c|c|c|c|c|c|c|c|c|c|c|c|c|c|c|}
\hline \multirow{2}{*}{$\begin{array}{l}\text { Sites } \\
\text { Elements }\end{array}$} & \multicolumn{4}{|c|}{ Le Casset } & \multicolumn{3}{|c|}{ Corsica } & \multicolumn{2}{|c|}{ Mallorca } & \multicolumn{3}{|c|}{ Lampedusa } & \multicolumn{3}{|c|}{ Frioul } \\
\hline & F1 & F2 & F3 & $\mathrm{F} 4$ & $\mathrm{~F} 1$ & $\mathrm{~F} 2$ & F3 & $\mathrm{F} 1$ & $\mathrm{~F} 2$ & $\mathrm{~F} 1$ & $\mathrm{~F} 2$ & F3 & F1 & $\mathrm{F} 2$ & F3 \\
\hline $\mathrm{Al}$ & 0.97 & & & & 0.97 & & & 0.99 & & 0.70 & -0.70 & & 0.88 & & \\
\hline $\mathrm{Fe}$ & 0.97 & & & & 0.99 & & & 0.99 & & 0.90 & 0.41 & & 0.98 & & \\
\hline $\mathrm{P}$ & 0.77 & & & 0.54 & 0.94 & & & 0.99 & & & & 0.93 & 0.71 & -0.31 & -0.51 \\
\hline $\mathrm{Ti}$ & 0.97 & & & & 0.99 & & & 0.99 & & 0.74 & -0.65 & & 0.95 & & \\
\hline Co & 0.35 & 0.93 & & & 0.82 & & 0.54 & 0.86 & 0.51 & 0.81 & -0.40 & & 0.89 & -0.33 & \\
\hline $\mathrm{Cr}$ & 0.98 & & & & 0.33 & 0.93 & & 0.99 & & 0.92 & & & 0.70 & 0.39 & 0.53 \\
\hline $\mathrm{Cu}$ & 0.80 & & 0.46 & & 0.95 & & & 0.99 & & 0.74 & 0.60 & & & 0.92 & \\
\hline $\mathrm{Mn}$ & 0.91 & & & & 0.96 & & & 0.99 & & 0.94 & & & 0.96 & & \\
\hline $\mathrm{Ni}$ & 0.98 & & & & 0.91 & & & 0.94 & & 0.72 & 0.38 & 0.52 & 0.86 & & 0.44 \\
\hline V & 0.98 & & & & 0.99 & & & 1.00 & & 0.77 & -0.62 & & 0.97 & & \\
\hline $\mathrm{Zn}$ & 0.76 & & 0.49 & & 0.97 & & & 0.98 & & 0.59 & 0.71 & & 0.52 & 0.79 & -0.30 \\
\hline $\begin{array}{l}\text { Cumulative } \\
\text { variances \% }\end{array}$ & 76.8 & 85.5 & 91.5 & 95.5 & 83.1 & 93.2 & 96.3 & 94.9 & 97.7 & 57.3 & 82.2 & 94.1 & 66.9 & 84.5 & 93.0 \\
\hline
\end{tabular}

\subsubsection{Characterization of CARAGA samples by mass ratios}

In order to identify the main source at each site, $\mathrm{Al}$ contents and mass ratios $\mathrm{X} / \mathrm{Al}$ were assessed because $\mathrm{Al}$ is a typical marker of dust particles. The mean $\mathrm{Al}$ contents in the CARAGA samples for the different sites were estimated by plotting total mass fluxes as a function of $\mathrm{Al}$ mass fluxes. The average of Al content, standard deviation and the determina- tion coefficient $\left(R^{2}\right)$ for every site are presented in Table 4. For the four stations of Corsica, Lampedusa, Le Casset and Mallorca, $R^{2} \geq 0.80$ and $\mathrm{Al}$ contents were typical of Saharan dust particles (Formenti et al., 2014). These values are also in agreement with the results of Guieu et al. (2002) on Al concentration in wet dust deposition ranging between 6.0 and $8.3 \%$. This indicates that African dust is the main contributor to the mass deposition fluxes, consistent with the conclusion by Vincent et al. (2016) that validated sampling and analyti- 


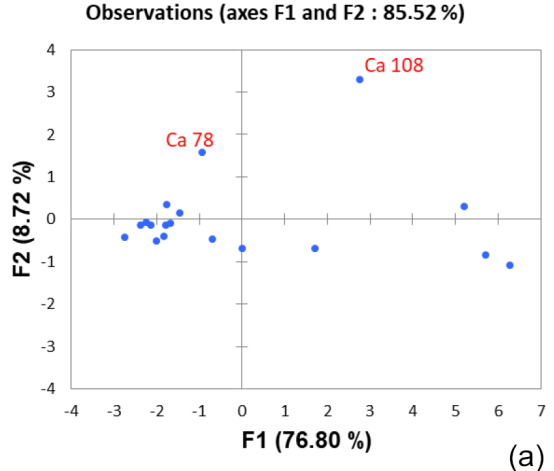

(a)

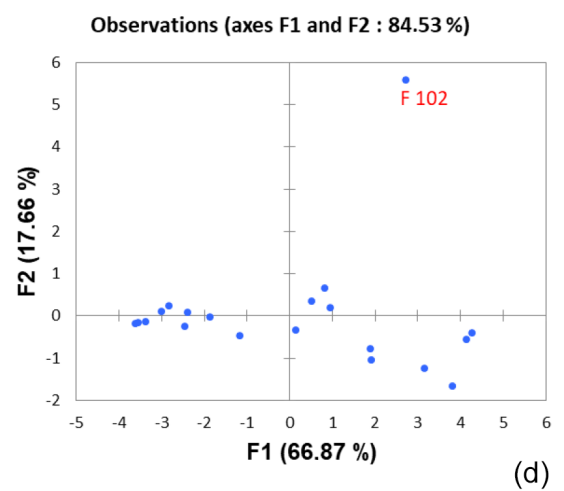

Observations (axes F1 and F3 : $82.73 \%$ )

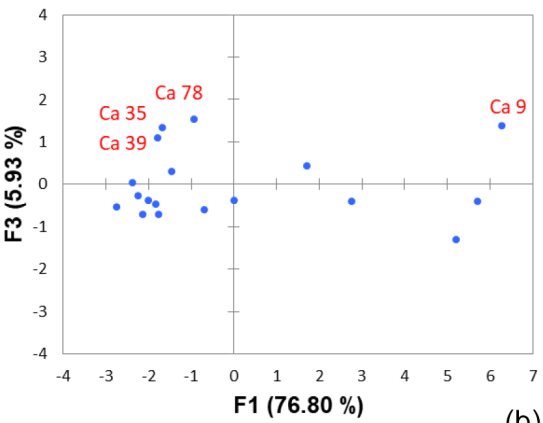

(b)

Observations (axes F1 and F3 : $75.34 \%$ )

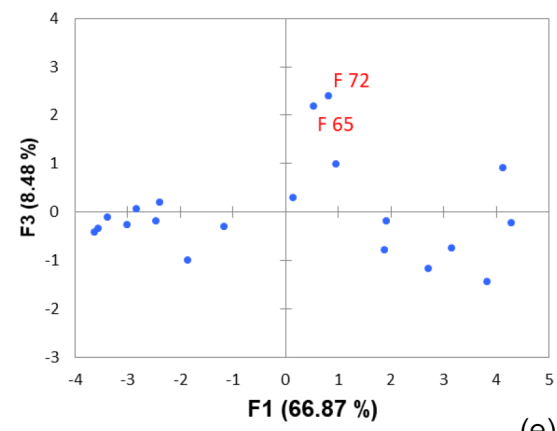

Observations (axes F1 and F2 : $93.20 \%$ )

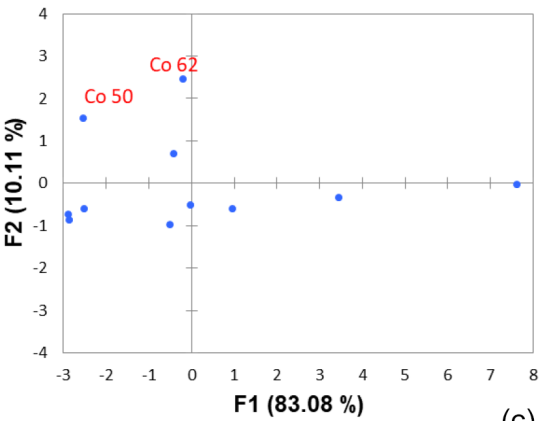

(c)

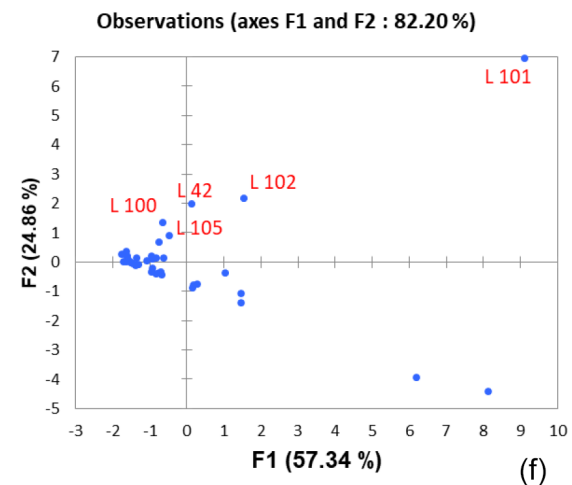

Figure 2. Outlier samples identified by PCA for four sampling sites: Le Casset, Corsica, Frioul and Lampedusa. (a) Outlier samples of Co at Le Casset. (b) Outlier samples of $\mathrm{Zn}$ and $\mathrm{Cu}$ at Le Casset. (c) Outlier samples of $\mathrm{Cr}$ at Corsica. (d) Outlier sample of $\mathrm{Zn}$ and $\mathrm{Cu}$ (and partially of $\mathrm{Cr}$ ) at Frioul. (e) Outlier samples of $\mathrm{Cr}$ at Frioul. (f) Outlier samples of $\mathrm{Zn}, \mathrm{Cu}$ and $\mathrm{Fe}$ at Lampedusa.

Table 4. Al contents in deposition samples for five sites: Le Casset, Corsica, Mallorca, Lampedusa and Frioul.

\begin{tabular}{lrrrrr}
\hline Sites & Le Casset & Corsica & Mallorca & Lampedusa & Frioul \\
\hline Mean $(\%)$ & 10.7 & 8.9 & 7.7 & 6.1 & 5.0 \\
\pm 1 SD $(\%)$ & 4.1 & 1.5 & 3.4 & 2.1 & 2.4 \\
$R^{2}$ & 0.86 & 0.91 & 0.99 & 0.80 & 0.35 \\
\hline
\end{tabular}

cal protocols. No clear correlation between $\mathrm{Al}$ concentrations and mass fluxes can be found in Frioul $\left(R^{2}=0.35\right)$, pointing out that the deposited mass could be influenced both by African dust and other aerosols particles, in agreement with PCA results.

It is also interesting to note that $\mathrm{Al}$ contents increased with a south to north gradient, i.e. with the lowest values at Lampedusa, the closest site to Saharan dust sources, and the highest values at Le Casset, the most distant site from Sahara (Table 4). Vincent et al. (2016) emphasized that most of the time the origin of the deposited dust changed from one sampling site to the other: dust samples collected at Le Casset were mainly transported from the western part of the Sahara, whereas dust arriving to Lampedusa generally came from Tunisia and Libya. Nevertheless, the values of the Al content were probably not only related to the provenance of dust, since the emission sources providing dust deposition in Corsica and in Mallorca were generally the same (Western Sahara/southern Morocco and Tunisia/eastern Algeria) (Vincent et al., 2016) and yet the Al content was different. Desboeufs et al. (2014b) observed an increase in the Al content in dust during its settling in the water column after deposition to the ocean. This increase was explained by the fact that the mass loss due to dissolution of the highest soluble species during settling modifies the mass percentage of the less soluble elements. The same effect could be observed in our samples due to the dissolution of soluble species during wet deposition as $\mathrm{Ca}$, whose solubility can be increased by conversion of calcite to Ca sulfate or Ca nitrate during longrange transport (Scheuvens et al., 2013). Vincent et al. (2016) showed that $80,63,60$ and $53 \%$ of studied samples corresponded to wet deposition events at Le Casset, Corsica, Lampedusa and Mallorca respectively. The increasing contribution of wet deposition with distance to the dust source is consistent with the obtained $\mathrm{Al}$ contents, since the farther from source the site is, the more important the number of wet deposition samples and the higher the Al content. The consistency of $\mathrm{Al}$ content values with the dust references confirms the Saharan origin of deposition and supports the reliability of CARAGA data. However, the variability of the soluble part with distance makes it difficult to use CARAGA samples 
to estimate the elemental content of deposition samples and hence to directly compare the composition of the deposition at the different sites. In the literature, inter-elemental mass ratios $\mathrm{X} / \mathrm{Al}$ are often used to characterize the dust chemical composition and source (e.g. Formenti et al., 2008). Furthermore, $\mathrm{Al}$ has a low solubility in water, and trace-metal solubility is also relatively low in dust $(<5 \%$ in Soil of Douz and $<11 \%$ in soil of Banizoumbou), so that such ratios should not be strongly affected by dissolution and hence can be used to validate the use of CARAGA samples to estimate the origin of atmospheric elemental fluxes.

The average of inter-elemental mass ratios $\mathrm{X} / \mathrm{Al}$, standard deviation (SD) and the determination coefficient $\left(R^{2}\right)$ for every site, and some references values are presented in Table 5. A correlation of $R^{2}>0.65$ was obtained between trace metals and $\mathrm{Al}$ contents regardless of the sampling site, and the $\mathrm{X} / \mathrm{Al}$ ratio were close to values found in the literature for Saharan dust, except for $\mathrm{Co}, \mathrm{Cr}, \mathrm{Cu}$ or $\mathrm{Zn}$ at Lampedusa, Frioul and to a lesser extent at Le Casset.

At Lampedusa, the correlation are relatively low $\left(R^{2}<0.6\right)$ for $\mathrm{Fe}, \mathrm{Cr}, \mathrm{Cu}, \mathrm{Mn}$ and $\mathrm{Zn}$. Excluding the five outlier samples (identified by PCA in Fig. 2f) (column Lampedusa* in the Table 5), we obtained better correlations with $R^{2}>0.7$ and a high consistency with reference dust values, except for $\mathrm{Zn}$. The average mass ratio $\left(35.08 \times 10^{-3}\right)$ was two times larger than references values $\left(1.50-1.70 \times 10^{-3}\right)$, which means that there was a very strong and frequent $\mathrm{Zn}$ anthropogenic source affecting deposition in Lampedusa during the sampling period. As a consequence, the atmospheric fluxes of $\mathrm{Zn}$ in Lampedusa could not be considered representative of dust deposition at this site. For the other trace metals, we can conclude that the main contribution of fluxes could be attributed to dust deposition during intense dust deposition event.

At Frioul, we already observed the low correlation of Al mass with total mass, showing a contribution of other sources of particles to the deposited mass. Indeed, Frioul is a rock/sand island in front of the industrialized city Marseille, which could be affected by resuspended mineral particles or by local anthropogenic sources. This conclusion is confirmed by the values of correlation found between $\mathrm{Al}$ and trace metals, as $\mathrm{Cr}, \mathrm{Cu}$ or $\mathrm{Zn}\left(R^{2}\right.$ between 0.01 and 0.24$)$, which were in general linked to one outlier sample (Fig. 2d) for $\mathrm{Zn}$ and $\mathrm{Cu}$ (31.3 and $64.5 \%$ in mass respectively), and four outlier samples (three points in Fig. 2d, e identified by PCA and another one identified by mass ratio $\mathrm{Cr} / \mathrm{Al}$ ) for $\mathrm{Cr}(46.6 \%$ in mass), However, even after removing the outlier points, the median mass ratios $\mathrm{Cr} / \mathrm{Al}\left(2.34 \times 10^{-3}\right)$, $\mathrm{Cu} / \mathrm{Al}\left(1.24 \times 10^{-3}\right)$ and $\mathrm{Zn} / \mathrm{Al}\left(11.29 \times 10^{-3}\right)$ are larger than dust reference values (Table 5). The $\mathrm{Zn} / \mathrm{Al}$ values were in agreement with the previous values obtained in the northwestern Mediterranean $\left(3-48 \times 10^{-3}\right)$ where a very high anthropogenic component was found for $\mathrm{Zn}$ (Guieu et al., 2010), and according to Table $3, \mathrm{Zn}$ and $\mathrm{Cu}$ had same origin. For this site, the interpretation of the chemical results is tricky, since even during intense dust events we suspect a mixing with other anthropogenic atmospheric compounds that may not be important in terms of mass but impact the chemical dust signature.

At Le Casset, $\mathrm{Cu}$ and $\mathrm{Zn}$ present correlations with $\mathrm{Al}$ with $R^{2}=0.26$ and 0.49 . This correlation is due to four outlier samples (identified in Fig. 2b). After excluding these samples influenced by anthropogenic sources, which present a low proportion in mass (14.9 and $10.7 \%$ for $\mathrm{Cu}$ and $\mathrm{Zn}$ respectively), the correlation coefficients are higher than 0.65 and the obtained ratios are consistent with reference values for Saharan dust $\left(\mathrm{Cu}: 0.43 \times 10^{-3}\left(0.38-0.50 \times 10^{-3}\right)\right.$ and Zn: $1.60 \times 10^{-3}\left(1.01-1.70 \times 10^{-3}\right)$ in Table 5). According to Table 3, a P source (factor of 4 ) influenced the site Le Casset, because of the agricultural contribution in this rural location, and two outlier samples were responsible for the low correlation of Co according to Fig. 2a. Thus, at Le Casset, the contribution of outlier samples lower than $15 \%$ for elemental mass fluxes and the good agreement between measured and referenced ratio confirm the main dust origin of $\mathrm{Co}, \mathrm{Cr}, \mathrm{Cu}$, $\mathrm{Fe}, \mathrm{Ti}, \mathrm{Mn}, \mathrm{Ni}, \mathrm{V}$ and $\mathrm{Zn}$ in deposition samples. In Corsica, the lowest correlation with $\mathrm{Al}$ obtained for $\mathrm{Cr}$ is due two outlier samples (in Fig. 2c), presenting $36.9 \%$ in Cr-deposited mass. Thus, at this site, the $\mathrm{Cr}$ fluxes correspond to a mix of dust and other sources. Finally, at Mallorca, the correlations higher than 0.6 (and even 0.9 excluding Co) show that the metal fluxes are typically associated with dust deposition.

A high correlation of $\mathrm{P}$ and $\mathrm{Al}$ is obtained at Mallorca $\left(R^{2}=0.97\right)$ and Corsica $\left(R^{2}=0.84\right)$ with a $\mathrm{P} / \mathrm{Al}$ ratio $(0.010-0.012)$ in agreement with typical dust composition (Table 5). We conclude that dust deposition was the main provider of $\mathrm{P}$ during intense dust event deposition at these sites. On the contrary, the non-linear trend obtained between $\mathrm{P}$ and $\mathrm{Al}$ fluxes at Le Frioul, Casset and Lampedusa shows that the $\mathrm{P}$ fluxes measured at these sites cannot be used for estimating P fluxes associated with dust deposition. The main parameters affecting $\mathrm{P}$ contents in atmospheric deposition are its fractional solubility (precipitation and duration of rain) or anthropogenic sources. To check the effect of dissolution, these ratios were calculated for dry and wet deposition separately, but no linear trend was obtained for dry nor for wet deposition samples. Concerning the anthropogenic influence, the non-linear trend is mainly due to a large repartition of data. It is therefore difficult to distinguish the fraction of $P$ from Saharan dust and anthropogenic or other sources at these three sites.

To conclude on the validation of CARAGA samples to estimate origin of atmospheric deposition, the results showed that the atmospheric deposition of trace metals at Le Casset, Corsica, Mallorca and Lampedusa is mainly associated with dust fluxes during intense dust event, except $\mathrm{Zn}$ in Lampedusa and $\mathrm{Cr}$ in Corsica. The outlier samples at these sites represented less than $10 \%$ of the deposited elemental mass. Thus the CARAGA samples can be used to estimate the atmospheric fluxes of these elements issued from dust deposition. On the contrary, the trace-metal composition of 
Table 5. Inter-elemental ratio in samples collected at the different CARAGA sites and reference values. Rf1: reference values in soils of Banizoumbou and Douz. Rf2: reference values in wet deposition of dust near emitting area (Desboeufs et al., 2010) or in total deposition with dust signature in the western Mediterranean Basin (Ridame et al., 1999; Guieu et al., 2010). Rf3: reference values in transported Saharan dust (Formenti et al., 2003, 2008, 2011 and 2014) for the Saharan-emitting sources (PSA 1 to 3: northern Algeria/southern Tunisia, Mauritania/Morocco and northern Mali/southern Algeria respectively), corresponding with the identified provenance of our samples (Vincent et al., 2016).

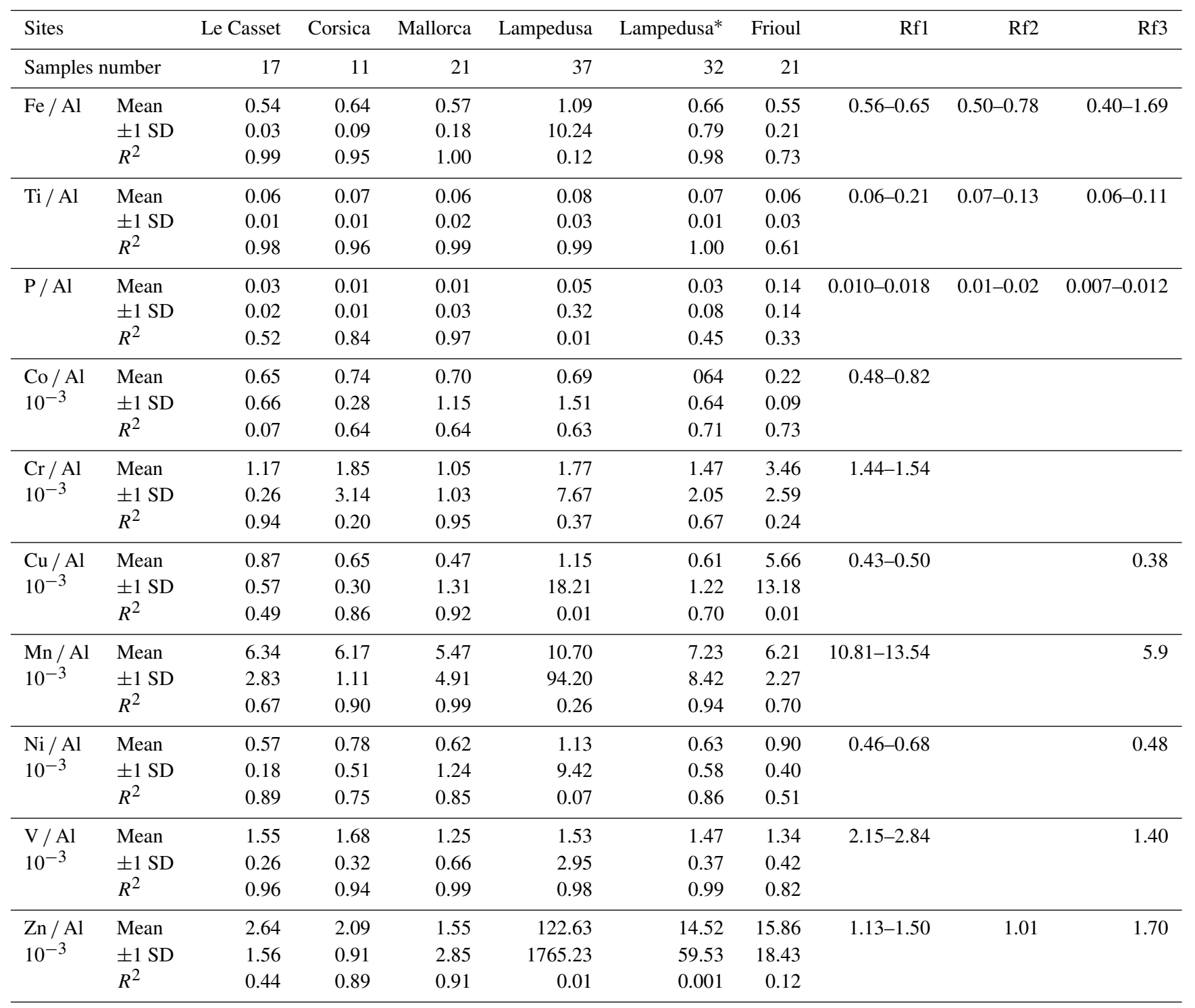

* Mean, standard deviation and correlation coefficient obtained after discarding four outlier samples for Lampedusa.

the CARAGA samples on Frioul was influenced by anthropogenic sources and the atmospheric fluxes are not representative of dust deposition even during intense dust events. This is also the case for P fluxes at the sites Le Casset, Frioul and Lampedusa, whereas P fluxes in Mallorca and Corsica can be used to estimate the dust-derived $\mathrm{P}$ deposition fluxes.

\subsection{Weekly mass fluxes of nutrients and trace metals}

The weekly mass fluxes of $\mathrm{P}$ and trace metals and percentage of wet deposition (wet only and mixed deposition according Vincent et al., 2016), estimated for 107 samples covering the 2011-2013 sampling period, are presented in Table 6. The trace-metal fluxes in Table 6 are presented in two categories: the fluxes mainly associated with dust deposition (sites of Le Casset, Corsica (except Cr), Mallorca and Lampedusa*), and the fluxes associated with deposition from a mixing of dust 
Table 6. Mean weekly mass fluxes of nutrients and trace metals for 107 intense events samples, standard deviation (SD) and contribution of wet deposition on total fluxes for five studied sites.

\begin{tabular}{|c|c|c|c|c|c|c|c|c|}
\hline \multirow[t]{2}{*}{ Sites } & & & \multicolumn{4}{|c|}{ Dust deposition } & \multicolumn{2}{|c|}{ Mixed deposition } \\
\hline & & & Le Casset & Corsica & Mallorca & Lampedusa* & Lampedusa & Frioul \\
\hline \multirow[t]{9}{*}{$\mathrm{mg} \mathrm{m}^{-2} \mathrm{wk}^{-1}$} & $\mathrm{Al}$ & Mean & 7.76 & 14.92 & 37.40 & 27.44 & 25.01 & 7.23 \\
\hline & & $\pm 1 \mathrm{SD}$ & 5.12 & 10.86 & 74.40 & 41.91 & 40.14 & 3.99 \\
\hline & & Wet $(\%)$ & 71 & 88 & 86 & 57 & 55 & 71 \\
\hline & $\mathrm{Fe}$ & Mean & 4.16 & 9.48 & 21.46 & 17.93 & 27.30 & 3.97 \\
\hline & & $\pm 1 \mathrm{SD}$ & 2.65 & 7.21 & 41.15 & 23.10 & 47.08 & 2.77 \\
\hline & & Wet $(\%)$ & 72 & 89 & 80 & 60 & 36 & 68 \\
\hline & $P$ & Mean & 0.24 & 0.19 & 0.37 & 0.99 & 1.16 & 0.99 \\
\hline & & $\pm 1 \mathrm{SD}$ & 0.16 & 0.13 & 0.54 & 1.41 & 1.64 & 1.16 \\
\hline & & Wet $(\%)$ & 79 & 91 & 80 & 67 & 51 & 60 \\
\hline \multirow[t]{21}{*}{$\mu \mathrm{g} \mathrm{m}^{-2} \mathrm{wk}^{-1}$} & $\mathrm{Co}$ & Mean & 5.04 & 11.46 & 26.10 & 17.48 & 17.27 & 1.57 \\
\hline & & $\pm 1 \mathrm{SD}$ & 5.77 & 6.33 & 26.48 & 16.34 & 16.31 & 1.27 \\
\hline & & Wet $(\%)$ & 80 & 90 & 69 & 49 & 44 & 75 \\
\hline & $\mathrm{Cr}$ & Mean & 9.05 & 33.03 & 39.11 & 39.80 & 44.23 & 25.02 \\
\hline & & $\pm 1 \mathrm{SD}$ & 4.25 & 20.84 & 54.76 & 41.16 & 48.19 & 20.22 \\
\hline & & Wet $(\%)$ & 69 & 87 & 79 & 57 & 46 & 77 \\
\hline & $\mathrm{Cu}$ & Mean & 6.73 & 10.14 & 17.43 & 16.84 & 28.88 & 40.94 \\
\hline & & $\pm 1 \mathrm{SD}$ & 2.50 & 4.50 & 19.02 & 12.84 & 51.70 & 115.52 \\
\hline & & Wet $(\%)$ & 65 & 84 & 76 & 64 & 34 & 82 \\
\hline & $\mathrm{Mn}$ & Mean & 49.21 & 91.24 & 204.68 & 194.93 & 261.70 & 44.92 \\
\hline & & $\pm 1 \mathrm{SD}$ & 31.68 & 79.30 & 349.24 & 273.03 & 421.64 & 26.65 \\
\hline & & Wet $(\%)$ & 69 & 91 & 81 & 65 & 43 & 67 \\
\hline & $\mathrm{Ni}$ & Mean & 4.40 & 12.05 & 23.14 & 19.59 & 28.23 & 6.48 \\
\hline & & $\pm 1 \mathrm{SD}$ & 2.14 & 5.79 & 28.49 & 21.15 & 38.19 & 3.90 \\
\hline & & Wet $(\%)$ & 68 & 84 & 83 & 66 & 41 & 73 \\
\hline & V & Mean & 12.01 & 25.16 & 46.72 & 40.20 & 38.30 & 9.68 \\
\hline & & $\pm 1 \mathrm{SD}$ & 6.56 & 17.26 & 75.20 & 58.24 & 55.39 & 6.62 \\
\hline & & Wet $(\%)$ & 70 & 88 & 81 & 59 & 55 & 70 \\
\hline & $\mathrm{Zn}$ & Mean & 20.47 & 32.15 & 58.00 & 345.48 & 3067.19 & 114.69 \\
\hline & & $\pm 1 \mathrm{SD}$ & 11.24 & 16.05 & 59.51 & 576.11 & 13063.10 & 153.65 \\
\hline & & Wet $(\%)$ & 70 & 85 & 76 & 61 & 7 & 72 \\
\hline
\end{tabular}

* Not including five outlier samples enriched in trace metals (especially Fe) in Lampedusa.

and other sources, as local or anthropogenic sources (sites of Lampedusa and Frioul). As observed by Vincent et al. (2016) on total dust mass fluxes, a north to south increasing gradient on $\mathrm{Al}$ and trace-metal inputs linked to dust deposition is observed with the lowest mean weekly mass fluxes on Le Casset and the highest for Mallorca. Even if the island of Lampedusa is the closest site to African sources, and the annual mass fluxes in Lampedusa are more important than in Mallorca (Vincent et al., 2016), the recorded weekly metalbearing dust fluxes on this site (Lampedusa* in Table 6) remains inferior to those recorded at Mallorca. Mass fluxes of $\mathrm{P}$ and trace metals linked to wet deposition are predominant at Le Casset, Corsica, Mallorca and Frioul (Table 6).
In Lampedusa, it appears that wet deposition predominates for dust deposition events (Lampedusa*), whereas the metal fluxes including anthropogenic sources are mainly from dry deposition. The lower dust metal fluxes found in Lampedusa* in comparison to Mallorca can be explained by the higher contribution of wet deposition in Mallorca. Inversely, the P fluxes found in Lampedusa* are the highest observed in the western basin, since P loss by dissolution induces a decrease of fluxes with the contribution of wet deposition. These results show that the fluxes of metals and $\mathrm{P}$ associated with wet deposition predominate in the western Mediterranean Sea environment. It has to be noted that, firstly, the mass fluxes estimated in this paper are averaged weekly mass fluxes for the 
most intense dust events that account for 50-84\% in mass of the total deposition, as studied by Vincent et al. (2016), so we could not compare them with references values in the literature which are typically annual. Secondly, due to the effect of dissolution during the CARAGA sampling protocol, these fluxes are underestimated in the worst case by $13 \%$ for $\mathrm{P}$ and $10 \%$ for $\mathrm{Zn}, \mathrm{Cu}$ and $\mathrm{Mn}$, and $5 \%$ for other trace metals.

\section{Conclusion}

The estimation of atmospheric deposition mass fluxes of nutrients and trace metals in the western Mediterranean Sea is critical to understand the role of dust deposition on phytoplankton activity. Few deposition measurements are available to document nutrient inputs for several years in the western Mediterranean Sea. To estimate these nutrients and mass fluxes of trace metals, we validated the possibility of using samples of mass measurements of atmospheric deposition performed under the same conditions with CARAGA collectors at five sites in the western part of the Mediterranean. A first step was to estimate elemental mass loss during the in situ collection and ignition protocol used for weighing samples. According to these tests with dust analogues and traffic soot, solubility larger than $15 \%$ was observed for major metals, such as $\mathrm{Ca}, \mathrm{Mg}$ and $\mathrm{K}$, excluding the possibility to use the common $\mathrm{Ca} / \mathrm{Fe}$ ratio to estimate source areas of deposited dust. However, the relative mass loss by dissolution of three aerosol analogues was lower than $3 \%$ for dust tracers like $\mathrm{Ti}, \mathrm{Al}, \mathrm{Fe}$ and trace metals such as $\mathrm{Cd}, \mathrm{Co}, \mathrm{Cr}, \mathrm{Ni}$ and $\mathrm{V}$. The relative mass loss by dissolution was up to $10 \%$ for $\mathrm{Zn}$, $\mathrm{Cu}$ and $\mathrm{Mn}$. For the major nutrient $\mathrm{P}$, this loss by dissolution ranged from 10 to $13 \%$. During the ignition, the elemental mass loss for tracer elements, nutrients and trace metals was not significant. These results point out that there is no bias due to the sampling method and the lab protocols used to estimate elemental fluxes from CARAGA atmospheric deposition samples.

Chemical analyses of 107 CARAGA samples corresponding to the most intense dust deposition events observed between 2011 and 2013 in the western basin were performed to validate using CARAGA samples in order to estimate the elemental mass deposition flux of nutrients and trace metals. After checking the chemical composition of samples using $\mathrm{PCA}, \mathrm{Al}$ content and inter-elemental mass ratios $\mathrm{X} / \mathrm{Al}$, the chemical composition of samples from all stations excluding Frioul have the typical chemical signature of Saharan dust, except for $\mathrm{Zn}$ in Lampedusa, $\mathrm{Cr}$ in Corsica and $\mathrm{P}$ in Le Casset and Lampedusa. These CARAGA samples were chemically exploitable and have been used to estimate $\mathrm{P}$ and trace-metal mass fluxes associated with dust deposition, keeping in mind the underestimation of soluble fraction. The deposition sampled at Frioul could be affected by other sources, even during an intense dust event, and hence elemental atmospheric fluxes measured at this site are linked to a mixing of dust and other relatively local sources.

The atmospheric elemental fluxes estimated from CARAGA samples constitute the first regional assessment of a mean weekly mass fluxes of trace metals and P linked to intense dust deposition over the western Mediterranean Basin. The mean mass fluxes were dependent on the distance to the source and on the contribution of wet deposition. High averages and strong standard deviations of $\mathrm{Al}$ (dust marker) mass fluxes were observed at Lampedusa and Mallorca due to several intense dust events. Extreme $\mathrm{Zn}$ mass fluxes $\left(122.63 \pm 1765.23 \mu \mathrm{g} \mathrm{m}^{-2} \mathrm{wk}^{-1}\right)$ were observed at Lampedusa, which need to be thoroughly investigated, but were likely due to the large use of non-ferrous metal manufacturing in this environment strongly impacted by sea spray. Knowing that a good representation of these intense fluxes is critical to estimate the role of atmospheric deposition on marine biosphere in modelling (Guieu et al., 2014), the parameterization of wet deposition of nutrients and trace metals needs to be improved.

Data availability. To obtain the data from the CARAGA network, contact Gilles Bergametti or Benoit Laurent at LISA (http: //mistrals.sedoo.fr/Database-Content/?project=ChArMEx).

Competing interests. The authors declare that they have no conflict of interest.

Special issue statement. This article is part of the special issue "CHemistry and AeRosols Mediterranean EXperiments (ChArMEx) (ACP/AMT inter-journal SI)". It is not associated with a conference.

Acknowledgements. This study received financial support from the MISTRALS (Mediterranean Integrated Studies at Local and Regional Scales) and ChArMEx (Chemistry-Aerosol Mediterranean Experiment) programmes and ADEME. The authors also want to thank all those who operated the CARAGA sites.

Edited by: Andrew Sayer

Reviewed by: two anonymous referees

\section{References}

Anderson, L. D., Faul, K. L., and Paytan, A.: Phosphorus associations in aerosols: What can they tell us about $\mathrm{P}$ bioavailability?, Mar. Chem., 120, 44-56, https://doi.org/10.1016/j.marchem.2009.04.008, 2010.

Arndt, J., Sciare, J., Mallet, M., Roberts, G. C., Marchand, N., Sartelet, K., Sellegri, K., Dulac, F., Healy, R. M., and Wenger, J. C.: Sources and mixing state of summertime background aerosol in the north-western Mediterranean basin, At- 
mos. Chem. Phys., 17, 6975-7001, https://doi.org/10.5194/acp17-6975-2017, 2017.

Artuso, F., Chamard, P., Piacentino, S., Sferlazzo, D. M., De Silvestri, L., di Sarra, A., Meloni, D., and Monteleone, F.: Influence of transport and trends in atmospheric $\mathrm{CO}_{2}$ at Lampedusa, Atmos. Environ., 43, 3044-3051, https://doi.org/10.1016/j.atmosenv.2009.03.027, 2009.

Ault, A. P., Williams, C. R., White, A. B., Neiman, P. J., Creamean, J. M., Gaston, C. J., Ralph, F. M., and Prather, K. A.: Detection of Asian dust in California orographic precipitation, J. Geophys. Res., 116, D16205, https://doi.org/10.1029/2010JD015351, 2011.

Başak, B. and Alagha, O.: The chemical composition of rainwater over Bqyqkçekmece Lake, Istanbul, Atmos. Res., 71, 275-288, 2004.

Becagli, S., Sferlazzo, D. M., Pace, G., di Sarra, A., Bommarito, C., Calzolai, G., Ghedini, C., Lucarelli, F., Meloni, D., Monteleone, F., Severi, M., Traversi, R., and Udisti, R.: Evidence for heavy fuel oil combustion aerosols from chemical analyses at the island of Lampedusa: a possible large role of ships emissions in the Mediterranean, Atmos. Chem. Phys., 12, 3479-3492, https://doi.org/10.5194/acp-12-3479-2012, 2012.

Becagli, S., Anello, F., Bommarito, C., Cassola, F., Calzolai, G., Di Iorio, T., di Sarra, A., Gómez-Amo, J.-L., Lucarelli, F., Marconi, M., Meloni, D., Monteleone, F., Nava, S., Pace, G., Severi, M., Sferlazzo, D. M., Traversi, R., and Udisti, R.: Constraining the ship contribution to the aerosol of the central Mediterranean, Atmos. Chem. Phys., 17, 2067-2084, https://doi.org/10.5194/acp17-2067-2017, 2017

Bergametti, G., Gomes, L. Remoudaki, E., Desbois, M., Martin, D., and Buat-Ménard, P.: Present Transport and Deposition Patterns of African Dusts to the North-Western Mediterranean, in: Paleoclimatology and Paleometeorology: Modern and Past Patterns of Global Atmospheric Transport, edited by: Leinen M. and Sarnthein M., NATO ASI Series (Series C: Mathematical and Physical Sciences), vol. 282, 227-252, Springer, Dordrecht, the Netherlands, 1989.

Bonnet, S. and Guieu, C.: Atmospheric forcing on the annual iron cycle in the western Mediterranean Sea: A 1-year survey, J. Geophys. Res., 111, C09010, https://doi.org/10.1029/2005JC003213, 2006.

Coddeville, P., Charron, A., Plaisance, H., and Galloo, J. C.: Détermination à l'aide d'un modèle récepteur des zones sources à l'origine des concentrations mesurées dans les précipitations collectées en trois sites du réseau MERA (France), Journal of Water Science, 15, 205-227, https://doi.org/10.7202/705493ar, 2002.

Desboeufs, K. V., Losno, R., and Colin, J. L.: Factors influencing aerosol solubility during cloud processes, Atmos. Environ., 35, 3529-3537, 2001.

Desboeufs, K. V., Sofikitis, A., Losno, R., Colin, J. L., and Ausset, P.: Dissolution and solubility of trace metals from natural and anthropogenic aerosol particulate matter, Chemosphere, 58, 195203, https://doi.org/10.1016/j.chemosphere.2004.02.025, 2005.

Desboeufs, K. V., Journet, E., Rajot, J.-L., Chevaillier, S., Triquet, S., Formenti, P., and Zakou, A.: Chemistry of rain events in West Africa: evidence of dust and biogenic influence in convective systems, Atmos. Chem. Phys., 10, 9283-9293, https://doi.org/10.5194/acp-10-9283-2010, 2010.
Desboeufs, K. V., Leblond, N., Wagener, T., Bon Nguyen, E., and Guieu, C.: Chemical fate and settling of mineral dust in surface seawater after atmospheric deposition observed from dust seeding experiments in large mesocosms, Biogeosciences, 11, 55815594, https://doi.org/10.5194/bg-11-5581-2014, 2014a.

Desboeufs, K. V., Losno, R., and Colin, J. L.: Factors influencing aerosol solubility during cloud processes, Atmos. Environ., 35, 3529-3537, 2014b.

Formenti, P., Elbert, W., Maenhaut, W., Haywood, J., and Andreae, M. O.: Chemical composition of mineral dust aerosol during the Saharan Dust Experiment (SHADE) airborne campaign in the Cape Verde region, J. Geophys. Res., 108, 8576, https://doi.org/10.1029/2002JD002648, 2003.

Formenti, P., Rajot, J. L., Desboeufs, K., Caquineau, S., Chevaillier, S., Nava, S., Gaudichet, A., Journet, E., Triquet, S., Alfaro, S., Chiari, M., Haywood, J., Coe, H., and Highwood, E.: Regional variability of the composition of mineral dust from western Africa: Results from the AMMA SOP0/DABEX and DODO field campaigns, J. Geophys. Res., 113, D00C13, https://doi.org/10.1029/2008JD009903, 2008.

Formenti, P., Schütz, L., Balkanski, Y., Desboeufs, K., Ebert, M., Kandler, K., Petzold, A., Scheuvens, D., Weinbruch, S., and Zhang, D.: Recent progress in understanding physical and chemical properties of African and Asian mineral dust, Atmos. Chem. Phys., 11, 8231-8256, https://doi.org/10.5194/acp11-8231-2011, 2011.

Formenti, P., Caquineau, S., Desboeufs, K., Klaver, A., Chevaillier, S., Journet, E., and Rajot, J. L.: Mapping the physicochemical properties of mineral dust in western Africa: mineralogical composition, Atmos. Chem. Phys., 14, 10663-10686, https://doi.org/10.5194/acp-14-10663-2014, 2014.

Gómez-Amo, J. L., Estellés, V., di Sarra, A., Pedrós, R., Sferlazzo, D., Utrillas, M. P., and Martínez-Lozano, J. A.: A comparison of Microtops II and satellite ozone measurements in the period 2001-2011, J. Atmos. Sol.-Terr. Phys., 94, 5-12, https://doi.org/10.1016/j.jastp.2012.12.012, 2013.

Goossens, D. and Rajot, J. L.: Techniques to measure the dry aeolian deposition of dust in arid and semi-arid landscapes: a comparative study in West Niger, Earth Surf. Proc. Land., 33, 178195, https://doi.org/10.1002/esp.1533, 2008.

Guieu, C., Loÿe-Pilot, M.-D. Ridame, C., and Thomas, C.: Chemical characterization of the Saharan dust end-member: Some biogeochemical implications for the western Mediterranean Sea, J. Geophys. Res., 107, ACH 5-1-ACH 5-11, https://doi.org/10.1029/2001JD000582, 2002.

Guieu, C., Loÿe-Pilot, M.-D., Benyahya, L., and Dufour, A.: Spatial variability of atmospheric fluxes of metals (Al, $\mathrm{Fe}, \mathrm{Cd}, \mathrm{Zn}$ and $\mathrm{Pb}$ ) and phosphorus over the whole Mediterranean from a one-year monitoring experiment: Biogeochemical implications, Mar. Chem., 120, 164-178, https://doi.org/10.1016/j.marchem.2009.02.004, 2010.

Guieu, C., Aumont, O., Paytan, A., Bopp, L., Law, C. S., Mahowald, N., Achterberg, E. P., Marañón, E., Salihoglu, B., Crise, Wagener, T., Herut, B., Desboeufs, K., Kanakidou, M., Olgun, N., Peters, F., Pulido-Villena, E., Tovar-Sanchez, A., and Völker, C.: The significance of the episodic nature of atmospheric deposition to Low Nutrient Low Chlorophyll regions, Global Biogeochem. Cy., 28, 1179-1198, https://doi.org/10.1002/2014GB004852, 2014. 
Heimburger, A., Losno, R., and Triquet, S.: Solubility of iron and other trace elements in rainwater collected on the Kerguelen Islands (South Indian Ocean), Biogeosciences, 10, 6617-6628, https://doi.org/10.5194/bg-10-6617-2013, 2013.

Journet, E., Desboeufs, K. V., Caquineau, S., and Colin, J.-L.: Mineralogy as a critical factor of dust iron solubility, Geophys. Res. Lett., 35, L07805, https://doi.org/10.1029/2007GL031589, 2008.

Kanakidou, M., Mihalopoulos, N., Kindap, T., Im, U., Vrekoussis, M., Gerasopoulos, E., Dermitzaki, E., Unal, A., Koçak, M., Markakis, K., Melas, D., Kouvarakis, G., Youssef, A. F., Richter, A., Hatzianastassiou, N., Hilboll, A., Ebojie,. F., von Savigny, C., Ladstaetter-Weissenmayer, A., Burrows, J., and Moubasher, H.: Megacities as hot spots of air pollution in the East Mediterranean, Atmos. Environ., 45, 1223-1235, https://doi.org/10.1016/j.atmosenv.2010.11.048, 2011.

Laurent, B., Losno, R., Chevaillier, S., Vincent, J., Roullet, P., Bon Nguyen, E., Ouboulmane, N., Triquet, S., Fornier, M., Raimbault, P., and Bergametti, G.: An automatic collector to monitor insoluble atmospheric deposition: application for mineral dust deposition, Atmos. Meas. Tech., 8, 2801-2811, https://doi.org/10.5194/amt-8-2801-2015, 2015.

López-García, P., Gelado-Caballero, M. D., Santana-Castellano, D., Suárez de Tangil, M., Collado-Sánchez, C., and HernándezBrito, J. J.: A three-year time-series of dust deposition flux measurements in Gran Canaria, Spain: A comparison of wet and dry surface deposition samplers, Atmos. Environ., 79, 689-694, 2013.

Loÿe-Pilot, M.-D. and Martin, J. M.: Saharan dust input to the western Mediterranean: an eleven years record in Corsica, in: The Impact of Desert Dust Across the Mediterranean, edited by: Guerzoni, S. and Chester., R., Kluwer, Dordrecht, the Netherlands, 191-199, 1996.

Loÿe-Pilot, M. D., Martin, J. M., and Morelli, J.: Atmospheric input of inorganic nitrogen to the Western Mediterranean, Biogeochem., 9, 117-134, https://doi.org/10.1007/BF00692168, 1990.

Mallet, M., Dulac, F., Formenti, P., et al.: Overview of the Chemistry-Aerosol Mediterranean Experiment/Aerosol Direct Radiative Forcing on the Mediterranean Climate (ChArMEx/ADRIMED) summer 2013 campaign, Atmos. Chem. Phys., 16, 455-504, https://doi.org/10.5194/acp-16-4552016, 2016.

Moon, J.-Y., Lee, K., Tanhua, T., Kress, N., and Kim, I-N: Temporal nutrient dynamics in the Mediterranean Sea in response to anthropogenic inputs, Geophys. Res. Lett., 43, 5243-5251, https://doi.org/10.1002/2016GL068788, 2016.

Morel, F. M. M. and Hudson, R. J.: The geobiological cycle of trace elements in aquatic systems: Redfield revisited, in Chemical Processes in Lakes, John Wiley and Sons, New York, USA, 251281,1985
Paris, R., Desboeufs, K. V., and Journet, E.: Variability of dust iron solubility in atmospheric waters: Investigation of the role of oxalate organic complexation, Atmos. Environ., 45, 6510-6517, https://doi.org/10.1016/j.atmosenv.2011.08.068, 2011.

Pulido-Villena, E., Rérolle, V., and Guieu, C.: Transient fertilizing effect of dust in P-deficient LNLC surface ocean, Geophys. Res. Lett., 37, L01603, https://doi.org/10.1029/2009GL041415, 2010.

Richon, C., Dutay, J.-C., Dulac, F., Wang, R., Balkanski, Y., Nabat, P., Aumont, O., Desboeufs, K., Laurent, B., Guieu, C., Raimbault, P., and Beuvier, J.: Modeling the impacts of atmospheric deposition of nitrogen and desert dust-derived phosphorus on nutrients and biological budgets of the Mediterranean Sea, Progr. Oceanog., 126, 98-108, https://doi.org/10.1016/j.pocean.2014.04.009, 2017.

Ridame, C., Guieu, C., and Loÿe-Pilot, M.-D.: Trend in total atmospheric deposition fluxs of aluminium, iron, and trace metals in the northwestern Mediterranean over the past decade (1985-1997), J. Geophys. Res., 104, 30127-30138, https://doi.org/10.1029/1999JD900747, 1999.

Ridame, C., Le Moal, M., Guieu, C., Ternon, E., Biegala, I. C., L'Helguen, S., and Pujo-Pay, M.: Nutrient control of $\mathrm{N}_{2}$ fixation in the oligotrophic Mediterranean Sea and the impact of Saharan dust events, Biogeosciences, 8, 2773-2783, https://doi.org/10.5194/bg-8-2773-2011, 2011.

Rontani, J.-F., Charriere, B., Vaultier, F., Garcia, N., Sempéré, R., and Raimbault, P.: Origin and degradation of lipids in aeolian particles from a coastal area of the north-western Mediterranean Sea, Atmos. Environ., 56, 124-135, 2012.

Rysman, J.-F., Verrier, S., Lemaître, Y., and Moreau, E.: Space-time variability of the rainfall over the western Mediterranean region: A statistical analysis. J. Geophys. Res.-Atmos., 118, 8448-8459, https://doi.org/10.1002/jgrd.50656, 2013.

Scheuvens, D., Schütz, L., Kandler, K., Ebert, M., and Weinbruch, S.: Bulk composition of northern African dust and its source sediments - A compilation, Earth Sci. Rev., 116, 170 194, https://doi.org/10.1016/j.earscirev.2012.08.005, 2013.

Schulz, M., Prospero, J. M., Baker, A. R., Dentener, F., Ickes, L., Liss, P. S., Mahowald, N. M., Nickovic, S., García-Pando C. P., Rodríguez, S., Sarin, M., Tegen, I., and Duce, R. A.: Atmospheric transport and deposition of mineral dust to the ocean: Implications for research needs, Environ. Sci. Technol., 46, 1039010404, https://doi.org/10.1021/es300073u, 2012.

Vincent, J., Laurent, B., Losno, R., Bon Nguyen, E., Roullet, P., Sauvage, S., Chevaillier, S., Coddeville, P., Ouboulmane, N., di Sarra, A. G., Tovar-Sánchez, A., Sferlazzo, D., Massanet, A., Triquet, S., Morales Baquero, R., Fornier, M., Coursier, C., Desboeufs, K., Dulac, F., and Bergametti, G.: Variability of mineral dust deposition in the western Mediterranean basin and south-east of France, Atmos. Chem. Phys., 16, 8749-8766, https://doi.org/10.5194/acp-16-8749-2016, 2016. 